\section{Closed doors}

SIR - Lord Ashby in his review of Victims of Science by Richard Ryder (Nature 8 September, p.163) refers to "lurid colour plates" depicting animals undergoing experimentation and drawn "for some unexplained reason" from countries other than Britain.

As the secretary of the society publishing the book, and as the photographer concerned, I feel impelled to point out that this is due entirely to the fact that I have never been allowed to witness and photograph any experiment on a live animal performed in a British laboratory, despite numerous requests to do so.

Those who forbid the taking of such photographs on their own premises are hardly in a position to criticize the use of material from other more forthcoming sources, and I challenge British laboratories to allow me to photograph exactly what is taking place in this country.

BRIANGUNN

The National Anti-Vivisection Society,

51 Harley Street,

London WIN IDD, UK

\section{Warsaw release}

SIR - On 30 July 1983 I found myself outside the gates of the Mokstow Prison in Warsaw, in consequence of the amnesty decreed by the Polish Parliament. This was two months before the end of the sixteen months' imprisonment to which I was sentenced for sending abroad some letters of critical comment on political developments in Poland. I am now enjoying my freedom, with a greater understanding than before of the aspects of normal life that have real importance. I have also now heard in detail about the many actions taken on my behalf in various countries, of which I was only partially aware in prison.

By this letter I express my sincere gratitude to all those individual scientists, university departments, academies and learned societies who protested that dissent should not be treated as a criminal of fence and who sought my early release. Perhaps I may repeat here what I stated during my numerous trials - namely, that I broke neither the existing laws of the country nor the unwritten laws of good citizens. For me personally the actions taken on my behalf showed that I had not been left alone, and they helped greatly to maintain my spirits and to at tempt to continue scientific work despite the conditions.

I also see in these protests a valuable demonstration of the solidarity of the international scientific community. I am by no means the only one to have suffered loss of freedom or imprisonment as a result of a political order, and I hope that similar efforts can be made on behalf of all those in such a position. Such actions do not of ten achieve the desired result immediately, but they nevertheless form links which strengthen each of the scientists involved and the scientific community as a whole. By contrast, the formal sanctions adopted by some organizations have had little effect on the governments against which they are directed and they do nothing for individual scientists. The vested interest in freedom of speech and enquiry which all scient ists have and their personal willingness to defend it seem to me to constitute one of the important forces for peace and progress in the present disturbed world.

RICHARDHERCYZNSKI

Warsaw, Poland

\section{Halley's comet}

SIR - In quoting a plethora of variations in the spelling of Halley, David Hughes (Nature 11 August, p. 119) has introduced a complicating factor which does not help much in trying to sort out how Halley's name was pronounced in his own day. Old chroniclers certainly did vary in the spelling they used, but so they would, since pronunciation varies depending on local dialect. The variations Hughes mentions come from a variety of sources spread widely over England; the one thing they demonstrate is that spelling names was done phonetically in the days before standardization.

The official documents he quotes make it pretty clear that the pronunciation "Hawley" (to rhyme with "poorly") was customary. Indeed, this is supported by Robert Hooke who, in his manuscript diary, uses the spelling "Hally" (pronounced Hall $+y$ ) rather than "Halley" (which would sound like David Hughes' recommendation of "Hal-ley"). And Hooke was noted for his use of phonetic spelling.

I feel that the argument is not how Halley's name was pronounced in his own day - it was, surely, "Hawley" - but whether we should continue with that pronunciation today. After all, spoken English has changed over the years and must now be different, in some respects at least, from what it was in the seventeenth and eighteenth centuries. Nevertheless my own preference is 10 use the pronunciation used by Halley's contemporaries, and presumably by Halley himself. After all, this is what we do with his first name Edmond, spelling it with an "o" as he did, instead of using the customary " $u$ ".

I do not find the late Sir Harold Spencer Jones' amusing piece of doggeral persuasive. Indeed, in the light of the expectation of cometographers like David Hughes that Halley's comet will make a pretty poor showing at its next apparition, I would support John Mason's new version:

Of all the comets in the sky

There's none like comet Halley,

We see it with the naked eye,

But this time rather poorly.

13 Acorn Avenue, COLIN A. RONAN Cambridge CB3 8DT, UK

DAVID HUGHES ADDS - The verse quoted in my article should be attributed to $\mathrm{H}$. $\mathrm{H}$. Turner (see Observatory 33, 150; 1910).

\section{The Coolidge effect}

SIR - In reading the article by J.S. Jones and L. Partridge (Nature 18 August, p.484), I thought at first that I was learning something new about the former US president, Calvin Coolidge. However, the explanation of the Coolidge effect was inconsistent with the personality of $\mathrm{Mr}$ Coolidge. If the phenomenon described had been called the Harding effect, I would not have given it a second thought!

More importantly, the authors have taken something out of context. An examination of the article in which the Coolidge effect is explained shows that the effect had nothing to do with President Coolidge's sexual habits. The term had its origin in a fable (of which there were many) about Coolidge (D.A. Dewsbury, Psychol. Bull. 89, 464):

One day President and Mrs Coolidge were visiting a government farm. Soon after their arrival they were taken off on separate lours. When Mrs Coolidge passed the chicken pens she paused to ask the man in charge if the rooster copulates more than once each day. "Dozens of times" was the reply. "Please tell that to the President," Mrs Coolidge requested. When the president passed the pens and was told about the rooster, he asked "Same hen every time?" "Oh no, Mr. Presidenı, a different one each time." The Presiden nodded slowly, then said "Tell that to Mrs Coolidge."

648 Vassar Road,

MORTON MALIN

Strafford,

Pennsylvania $19087 m$, USA

\section{Catch flies alive}

SIR - E.G. Gray gave instructions how to swat flies (Nature 25 August, p.678). Here is a method that I have often used to catch spiders, flies, mosquitoes and so on. Cut a piece of thin, stiff, smooth cardboard so that it is large enough amply to cover a plastic beaker. The beakers I use are the white plastic, "throwaway" beakers as used in coffee machines. Hold the beaker near the bottom with your hand well hidden from your "game". Approach the target from the back and behind and quietly place the beaker over the animal, being careful not to squash beaker or beast. Carefully slide the cardboard between the beaker and the wall or glass pane that the animal is sitting on. Keeping the beaker closed remove the combination and dispose at your discretion.

I presume that this works because the beaker is too light and too little structured with too little contrast to be seen or perhaps to be recognized as a threat. Note that shining a light on such creatures will often not trigger any flight. In view of the above perhaps the whiteness of Gray's tissue paper might be part of the trick.

PERCY N. KRUYTHOFF

Welterdreef 161 ,

2253 LJ Voorschoten,

The Netherlands 